\title{
CONGRESSIONAL CONTROL OF THE COURTS: A THEORETICAL AND EMPIRICAL ANALYSIS OF EXPANSION OF THE FEDERAL JUDICIARY*
}

\author{
JOHN M. DE FIGUEIREDO \\ University of \\ California, Berkeley
}

\author{
and
}

\author{
EMERSON H. TILLER \\ University of \\ Texas at Austin
}

\begin{abstract}
Congress has many available tools to influence the federal judiciary. In this article, we consider Congress' ability to balance, or stack, the courts through the creation of federal judgeships. While caseload pressure often produces the need for more judgeships, we demonstrate that political party alignment between Congress and the president often determines the timing of the judicial expansion. The net effect of expanding during political alignment is to speed up changes in the political balance of the judiciary in favor of the current Congress. We also examine the determinants of expansion size and show that both political alignment and caseload pressure influence Congress' decision regarding how many judgeships to add.
\end{abstract}

\section{INTRODUCTION}

7

ONGREss controls the federal judiciary, and, on occasion, it does so in ways so far-reaching that the course of judicial policy making can be altered for decades. One congressional strategy, in particular, can rein in the judiciary with remarkable force and direction. Simply put, Congress can selectively increase the number of judgeships in the federal judiciary, creating judicial vacancies where they would otherwise not be, and install judicial agents, through a like-minded president, who will share policy preferences congruent with those of the congressional majority. ${ }^{1}$ The net effect is to un-

* This article benefited from the comments of seminar participants at the Hoover Seminar on Collective Choice, Stanford University and the Institutional Analysis Workshop at the University of California, Berkeley. Glenn Carroll, Frank Cross, Patrick Moreton, David Mowèry, Sam Peltzman, Trond Petersen, Pablo Spiller, Klaus Toft, Richard Vanden Bergh, Barry Weingast, and Oliver Williamson all provided useful comments. Bronwyn Judkins, Charles North, Joseph Smith, and Kim Van Winkle each provided essential research assistance. We thank the John M. Olin Foundation for generous financial support.

1 Most vacancies occur as judges retire. Waiting for voluntary vacancies, however, can be a very time-consuming and inefficient way for Congress to exercise control over the judiciary. The majority of retirements which do occur generally come from judges who share the same political party affiliation as that of the current president. See James F. Spriggs \& Paul J. Wahlbeck, Calling It Quits: Strategic Retirement on the Federal Courts of Appeals, 19831991, 48 Pol. Res. Q. 573 (1995); and Deborah J. Barrow \& Gary Zuk, An Institutional Analysis of Turnover in the Lower Federal Courts, 1900-1987, 52 J. Pol. 457 (May 1990).

[ Journal of Law and Economics, vol. XXXIX (October 1996)]

(C) 1996 by The University of Chicago. All rights reserved. 0022-2186/96/3902-0003\$01.50 
dermine the influence of politically opposed judges holding positions on the bench and to concentrate within the judiciary a core of judges with a political ideology that is consistent with the preferences of Congress. Legislative majorities would then enjoy the benefits of having a judiciary in place that will ensure that the "right" policies are achieved in court, thereby relieving the legislature of costly intervention. ${ }^{2}$ In short, judicial expansion offers a politically efficient, if not insidious, control mechanism for the legislature.

While the ability of the president to transform the political makeup of the federal judiciary through the appointment process has been well documented and discussed, ${ }^{3}$ much less has been said about the ability of Congress to change the makeup of the judiciary to foster congressional aims. ${ }^{4}$ Indeed, the ability of the Senate and the House to control the federal judiciary through structural design has received scant theoretical or empirical treatment even though congressional manipulation of the judiciary has had

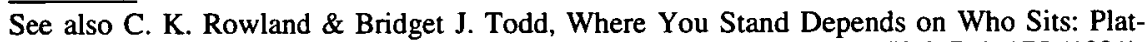
form Promises and Judicial Gatekeeping in the Federal District Courts, 53 J. Pol. 175 (1991), who find that judicial decisions reflect the ideology of the president who appointed the judge. Moreover, even if Congress and the president are politically aligned, Congress cannot force a discordant judge to retire.

${ }^{2}$ Congress can exercise a degree of control over the judiciary by overriding judicial decisions. For this to work, the legislature must monitor judicial decisions and change the unfavorable outcomes piecemeal through substantive legislation. The threat of such selective intervention by the legislature supposedly cabins the policy discretion of the courts who wish for their decisions to withstand the scrutiny of the other political branches. This override threat, however, often suffers from the inability of the House, Senate, and president to act collectively to discipline the courts because transaction costs are often high for each piece of override legislation, especially if the override must come as a constitutional amendment. See Pablo T. Spiller \& Matthew Spitzer, Judicial Choice of Legal Doctrines, 8 J. L. Econ. \& Org. 8 (1992), for a model of how the Supreme Court, by issuing constitutional decisions, can resist congressional attempts to control its policy outcomes. See also William N. Eskridge, Jr., Overriding Supreme Court Statutory Interpretation Decisions, 101 Yale L. J. 331 (1991), for a discussion of congressional overrides.

${ }^{3}$ For example, see Lettie M. Wenner \& Cynthia Ostberg, Restraint in Environmental Cases by Reagan-Bush Judicial Appointments, 77 Judicature 217 (1994); Sheldon Goldman, Reagan's Judicial Legacy: Completing the Puzzle and Summing Up, 72 Judicature 318 (1989); Timothy B. Tomasi \& Jess A. Velona, All the President's Men? A Study of Ronald Reagan's Appointments to the U.S. Court of Appeals, 87 Colum. L. Rev. 766 (1987).

${ }^{4}$ For an exception, consider Christopher E. Smith, Courts, Politics, and the Judicial Process 235 (1993) ("the creation of new judgeships inevitably places extra influence on the composition of the judiciary in the hands of political interests that control the judicial selection mechanisms at a given moment. An increase in federal appellate judgeships permits the political party that controls the presidency to appoint its partisans to these authoritative, policy-making positions. Thus, for example, when there is a Republican in the White House, Democratic members of Congress will be reluctant to create many new judgeships"). Also see Mathew D. McCubbins, Roger G. Noll, \& Barry R. Weingast, Politics and the Courts: A Positive Theory of Judicial Doctrine and the Rule of Law, 68 S. C. L. Rev. 1631 (1996), which argues that Congress can expand the doctrinal limits of the Supreme Court by increasing the number of lower court judges with differing policy preferences. 
a long history in the United States, dating from the earliest years of our republic. Consider the Judiciary Act of 1801 . The November election of 1800 brought the defeat of the Federalists, who had controlled the House, Senate, and the presidency since $1789,{ }^{5}$ and ushered in the new DemocraticRepublican majority in both chambers of the Seventh Congress along with control of the presidency. Prior to their departure, the Federalist Congress and president, John Adams, in the last month of their term, enacted the Judiciary Act of 1801 . The act created 18 judgeships, the so-called midnight judges, to staff the six newly created circuit courts. Although the need for judicial reform had long been recognized, ${ }^{6}$ the act was passed, and judges appointed and confirmed, only in the waning hours of Federalist power creating what the Federalists hoped would be a source of judicial influence for many years to come. ${ }^{7}$ The newly elected Democratic-Republicans, however, undermined the Federalists by quickly repealing the act of $1801 .^{8}$ New president Thomas Jefferson, who felt that the new appellate court was too politically partisan for his liking, signed the repeal, commenting that he was "lopping off the parasitical plant engrafted at the last session on the judiciary body." "The politics of judicial expansion had begun.

The passage of the Evarts Act of 1891 could also be construed as a politically motivated expansion. The act, which created circuit appellate courts and nearly doubled the number of federal appellate judges, was passed on March 3,1891, the day before a newly elected 52d Congress was to take power. In the 51st Congress, the House, Senate, and presidency were all controlled by the Republican Party. On March 4, however, a Democratically controlled House of Representatives would be sworn in (while the Senate and president were to remain under Republican control). Because the 51st Congress approved the expansion before the changeover, the Re-

${ }^{5}$ With the exception of 1793-95, when the House was not under Federalist control.

${ }^{6}$ In 1792, the justices of the Supreme Court petitioned then-President George Washington to reform the circuit process. Indeed, as early as 1790, Attorney General Edmund Randolph had prepared a report at the request of Congress suggesting many of the reforms eventually included in the Judiciary Act of 1801. Edwin C. Surrency, History of the Federal Courts 1920 (1987).

7 The outgoing Congress also created new justices of the peace for the District of Columbia. Four of these justices had not received their commissions prior to the inauguration of the Jefferson administration. They sought an order from the Supreme Court directing the new Secretary of State James Madison to deliver their commissions. This led to the landmark case of Marbury v. Madison, 5 U.S. 137 (1803), where the Supreme Court held that it had the power of judicial review-that is, the judicial power to control Congress when Congress oversteps its constitutional limitations. Adams appointed all of the judges to all of the circuits except the 5th Circuit because those potential judges did not accept the commission.

${ }^{8}$ The Judiciary Act of 1802.

${ }^{9}$ Letter from Thomas Jefferson to Benjamin Rush, December 20, 1801, quoted in Jeffrey B. Morris, Federal Justice in the Second Circuit 35 (1987). 
publican president and Republican controlled Senate of the 52d Congress were able to nominate and confirm judges of their Republican liking, much to the protestations of the new Democratic House. In this case, strategic timing of expansion by one congress was used to bypass potential obstructions of an oncoming house of representatives. There are other expansions which could be interpreted similarly.

These instances in American history exemplify what we believe has been a necessary political condition for the creation of judgeships: the House and Senate that enact the expansion legislation must expect the nominating president and the confirming Senate to appoint judges who will have political preferences consistent with those of the enacting Congress. ${ }^{10}$ This will generally occur only when the nominating president ${ }^{11}$ and the confirming Senate are of the same political party as the enacting House and Senate. When the enacting Congress and the nominating president (or confirming Senate) are not politically aligned, judicial expansion has less to offer as an efficient control mechanism because the nominees offered by the president (or those which could be confirmed by the Senate) will have political preferences inconsistent with at least one chamber of the enacting Congress. Moreover, knowing that large expansions can shift the preferences of the judiciary more quickly than small expansions, each congressional chamber should be willing to allow an aligned president (and aligned Senate) a greater share of new appointments than would be allowed a nonaligned president, if expansions were to occur at all during periods of nonalignment.

This theory of congressional control highlights the difference between "political efficiency" and "institutional efficiency" rationales for judicial expansion. ${ }^{12}$ Political efficiency concerns the ability of Congress to design a judiciary which most efficiently achieves political outcomes desired by Congress. Expansion would be efficient in that it would relieve legislators of the cost of monitoring and intervening in judicial decision making. This goal is furthered by expanding the judiciary and stacking the courts with like-minded judges. Institutional efficiency, in contrast, concerns the ability

${ }^{10}$ Note that we separate out the "enacting" Senate and House from the "confirming" Senate and future House. This distinction is meant to emphasize the fact that the House and Senate which enacts (or is considering enacting) expansion legislation may not be the same House and Senate which controls when nominations and appointments are subsequently made.

${ }^{11}$ Gary Zuk, Gerald S. Gryski, \& Deborah J. Barrow, Partisan Transformation of the Federal Judiciary, 21 Am. Pol. Q. 439 (1993). Zuk et al. show that, since President Grant, every president has successfully appointed to judicial vacancies people from his own party at least 80 percent of the time. The overall average same party appointment rate during that 120 -year time period is 93 percent.

${ }_{12}$ See George J. Stigler, Law or Economics? 35 J. Law \& Econ. 455, 459 (1992), for the argument that efficiency is to be judged only with respect to the goals one seeks. 
of Congress to design a judiciary which efficiently performs its public interest functions (that is, deciding cases fairly in a cost efficient and timely manner, irrespective of politics). This goal is furthered by staffing the courts with enough judges to handle the increasing caseloads.

Our first claim, then, is that the timing of judicial expansion is motivated by political efficiency. Since political alignment creates a strategic moment for officeholders to create a politically efficient judiciary, we expect political alignment to be, in general, a necessary condition for expansion. This proposition offers a challenge to the institutional efficiency explanation which suggests that the timing of expansion is due to increasing caseload burdens on the current judiciary, without considering political motivations of legislators.

Our second claim, however, is that the number of judgeships authorized in a given expansion is a function of both political efficiency and institutional efficiency. Although Congress often delays its decision to expand the judiciary to a politically favorable moment, when it does decide to expand, Congress takes caseload burdens into account in deciding on the number of new judgeships. Moreover, in those rare instances that a nonaligned Congress authorizes expansion, it will create fewer judgeships than an aligned government would create, ceteris paribus. Thus we argue that both caseload and politics factor into the decision making process of Congress in determining the number of judgeships created. Figure 1 illustrates our theory. The figure suggests that the timing of expansion is a step function driven by politics whereas the size of expansion is a function of both institutional pressure (caseloads) and political efficiency.

In Section II, we address institutional efficiency explanations for judicial expansion focusing in particular on caseload pressure and requests from within the judiciary for more judgeships. Section III develops a model about the timing of judicial expansion and is based on our political alignment (political efficiency) rationale. We then test our "alignment" model against the caseloads explanation (institutional efficiency) using data on both the Supreme Court and the federal appellate courts. We find that our hypothesis is strongly supported by the evidence. In Section IV we construct a model relating to the size of expansion and again test the effects of political alignment and caseloads. We find that both political alignment and caseloads play an important role in determining the number of new judgeships. Our conclusions are set out in Section V.

\section{Institutional EFFICIENCY EXPLANATIONS FOR EXPANDING THE JUDICIARY}

Our model offers a challenge to other explanations of judicial expansion. We consider two of them here: (1) caseload pressure and (2) requests for 


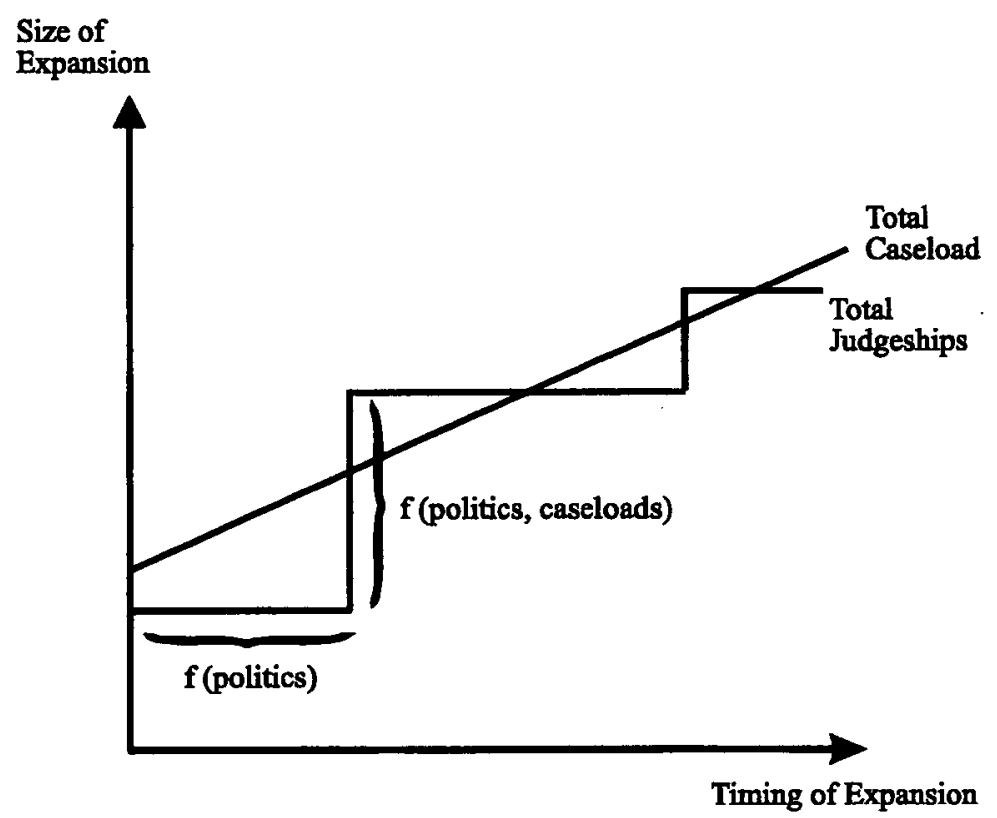

FIGURE 1.-Graphical scheme of the theory

help from the judiciary itself. In contrast to our model, both rely on "apolitical," institutional efficiency reasoning. That is, the timing and size of judicial expansion is supposedly driven by the desire for efficient judicial decision making rather than political manipulation.

\section{A. Increasing Caseloads}

Consider first caseload pressure. Briefly stated, this viewpoint argues that the courts face ever increasing caseloads and judges are unable to dispense with cases in a timely and efficient manner. This causes large backlogs of cases, "poor" decisions, and attrition of experienced judges. Moreover, high caseloads cause constituents to become exasperated with the courts and this, in turn, threatens the legitimacy of the federal judicial system. In order to avoid all of these negative effects, Congress periodically authorizes new judgeships to reflect the increasing caseloads. This relieves the current cadre of judges from the burden of hearing too many cases, rendering bad decisions, and dispensing of cases in an ad hoc manner. Figure 2 shows that, indeed, as caseloads have increased over time so has the number of judgeships authorized by Congress. A measure of the effect of caseload 


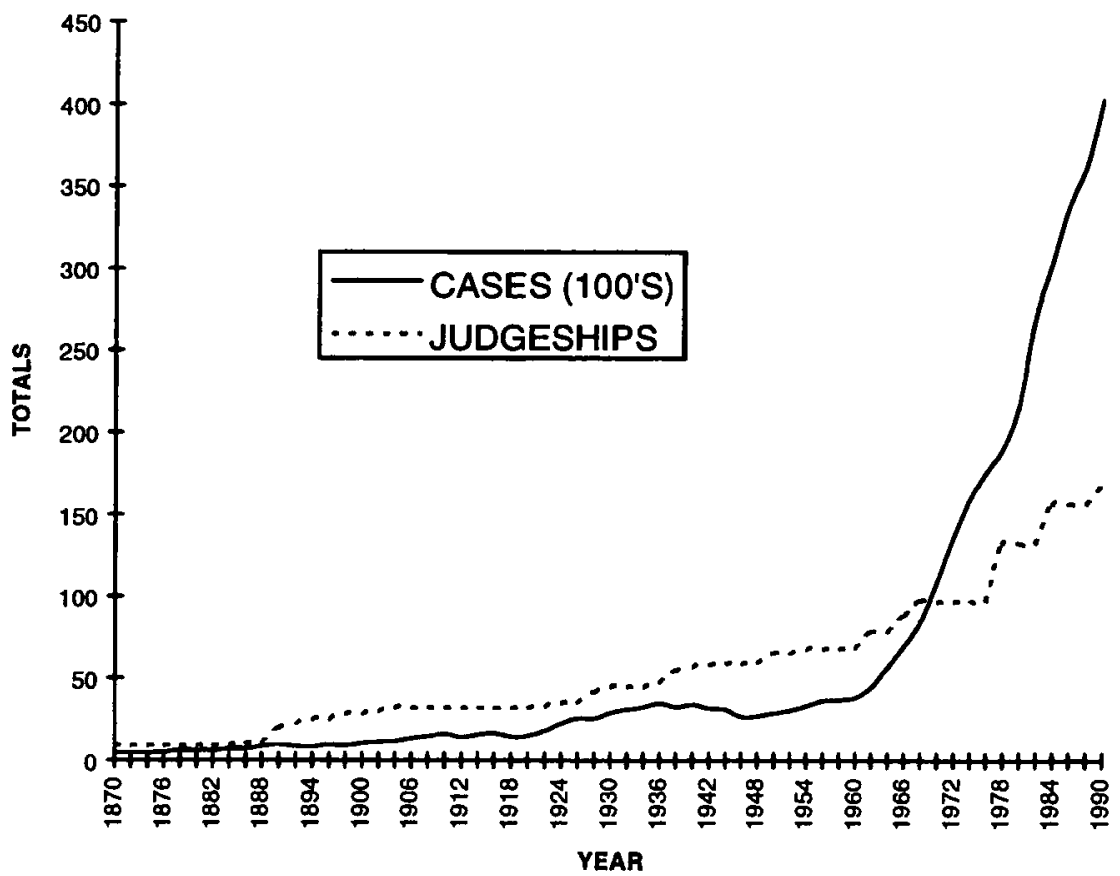

FIGURE 2.-Cases and judgeships in the federal courts of appeal, 1869-1990

pressure on judicial expansion is needed. Accordingly, we include caseload growth in the specification of our econometric models in Sections III and IV below. ${ }^{13}$

${ }^{13}$ References to caseloads as the determinant of judicial expansion are found throughout the legal literature. For example, see Kenneth W. Starr, The Supreme Court and the Federal Judicial System, 42 Case W. Res. L. Rev. 1209, 1211-1212 (1992) ("It is a truism that there has been an explosion in the caseload of both courts, and at the same time a considerable expansion of the size of the judiciary itself. The judgeship bills of 1978, 1984 and 1990 have brought the lower federal courts to a very different size than just 15 years ago. The driving reason for that expansion has been, of course, the expansion in the caseload itself' (footnotes omitted)); Pamela Mathy, Experimentation in Federal Appellate Case Management and the Prehearing Conference Program of the United States Court of Appeals for the Seventh Circuit, 61 Chi. Kent. L. Rev. 431, 457 (1985) ("the traditional response to growth in the caseload has been to increase the number of judgeships.'); Thomas E. Baker, An Assessment of Past Extramural Reforms of the U.S. Courts of Appeals, $28 \mathrm{Ga}$. L. Rev. 863, 881 (1994) ("During their first decade, the nine courts of appeals were assigned thirty judgeships; today there are thirteen federal circuits with 179 circuit judgeships. Increases have followed the congressional palliative of dealing with caseload growth by creating judgeships. This has been the most frequent and predictable congressional response to caseload growth" (footnotes omitted)). See also Jon O. Newman, Restructuring Federal Jurisdiction: Proposals to Preserve the Federal Judicial System, 56 U. Chi. L. Rev. 761 (1989). 


\section{B. Requests from within the Judiciary}

A related explanation for judicial expansion is that Congress responds to requests from the judiciary itself. Because the judiciary can best identify its own needs and is an impartial arbiter of the welfare of litigants who bring their cases to the Court, the requests of the judiciary for new judgeships provide a means for Congress to ensure quality decisions are made and the integrity of the judiciary maintained. The requests from the judiciary take into account many variables including workload projections, procedural improvements, compliance with the Speedy Trial Act, and the speed and ability of judges to dispose of cases of all kinds. ${ }^{14}$

Some history is useful here. In 1922, at the urging of Chief Justice Taft, Congress created the Judicial Conference of the United States to oversee and make recommendations to Congress "as may seem in the interest of uniformity and expedition of business" of the courts. ${ }^{15}$ During its first 40 years, the Judicial Conference made recommendations for changes in procedures, structure, and additional judgeships in an ad hoc and relatively unsystematic manner. ${ }^{16}$ In 1964, the Judicial Conference ordered the Administrative Office of the Courts to develop a more formal and systematic means for the federal judiciary to request, evaluate, and recommend additional judgeships from Congress based on the needs of the courts. Since then, the Judicial Conference has made recommendations to the Congress approximately every 2 years as to the number and location of new judgeships.

If judicial requests were the critical determinant of expansion, then the timing and number of judgeships approved by Congress should reflect the careful and methodical analysis of the Judicial Conference. This is rarely the case. Table 1 reflects the primary differences between the Judicial Conference requests and congressional action. First, the timing of congressional action bears little resemblance to the timing of the recommendations. Indeed, since 1965, the Judicial Conference has made 14 requests to Congress for additional appellate judgeships. On only five of these requests (37 percent) has Congress acted. ${ }^{17}$ Second, when Congress decides to take up a request, it often does not create the same number of judgeships as requested by the Judicial Conference. Of the five recommendations on which Con-

${ }^{14}$ Federal Judicial Center, Administrative Office of the Courts, History of the Authorization of Federal Judgeships Including Procedures and Standards Used in Conducting Judgeships Surveys (1991).

is 42 Stat. 838 (1922).

16 Surrency, supra note 6 , at 82.

17 We note, however, that the large expansions of 1977 and 1983 were peak request years by the Judicial Conference. This might suggest that the Judicial Conference anticipates when requests are more likely to be granted. On the other hand, it may suggest that requests merely accumulate until an expansion occurs. 
TABLE 1

Congressional RESPonses to Judiciary REQuests FOR ADDITIONAL JUDGES, 1965-91

\begin{tabular}{|c|c|c|}
\hline \multicolumn{2}{|c|}{$\begin{array}{l}\text { REQUESTS OF THE } \\
\text { JUDICIAL CONFERENCE }\end{array}$} & \multirow{2}{*}{$\begin{array}{c}\text { CONGRESSIONAL ACTION } \\
\text { NUMBER OF JUDGESHIPS } \\
\text { AUTHORIZED* }\end{array}$} \\
\hline Year & $\begin{array}{c}\text { Number of Judgeships } \\
\text { Requested }\end{array}$ & \\
\hline 1965 & 3 & 6 \\
\hline 1967 & 8 & 9 \\
\hline 1971 & 10 & 0 \\
\hline 1972 & 11 & 0 \\
\hline 1974 & 13 & 0 \\
\hline 1977 & 25 & 35 \\
\hline 1980 & 11 & 0 \\
\hline 1982 & 22 & 0 \\
\hline 1983 & 24 & 24 \\
\hline 1984 & 5 & 0 \\
\hline 1986 & 13 & 0 \\
\hline 1988 & 16 & 0 \\
\hline 1990 & 20 & 11 \\
\hline
\end{tabular}

* Year of authorization may differ from year of request.

gress has acted, only once (1984) was the number of new judgeships commensurate with the request of the Judicial Conference. ${ }^{18}$

Finally, even when new judgeships are legislated, they are often not allocated to the federal district court or the appellate court where the need has been determined by the Judicial Conference. For instance, in both 1984 and 1990, Congress allotted judges to locations for which positions the Judicial Conference had not requested and refused to assign judgeships to various locations where the conference did request slots. ${ }^{19}$ In short, this suggests

${ }^{18}$ In 1964, the Judicial Conference reported that no more than nine active judgeships could be allotted to one appeals court without impairing the efficiency of its operation and its unity as a judicial institution. Just 4 years later, Congress expanded the Fifth Circuit to 13 permanent appellate judgeships, thereby ignoring the request of the judiciary. Richard A. Posner, The Federal Courts: Crisis and Reform 762 n.3 (1983).

19 The Federal Judicial Center noted that "[j]udgeships are not necessarily created in the courts that need them most. As the Court Administration and Case Management Committee puts it, [in the case of] the retirement of a judge in a modestly burdened court . . . [Congress] provides a new judge and a senior judge to that court while judges in a nearby heavily burdened court will face continued over work and growing backlogs." Congress responded to the 1990 request with new district judgeships in Wyoming, Maine, New Hampshire, Pennsylvania, North Carolina, Tennessee, Hawaii, Washington, Utah, Florida, and Georgia, all of which were not requested by the Judicial Conference. For each of these, another district judgeship requested by the Judicial Conference was denied. Gordon Bermant, William Schwarzer, Edward Sussman, \& Russell Wheeler, Imposing a Moratorium on the Number of Federal Judges 53-54 (1993). 


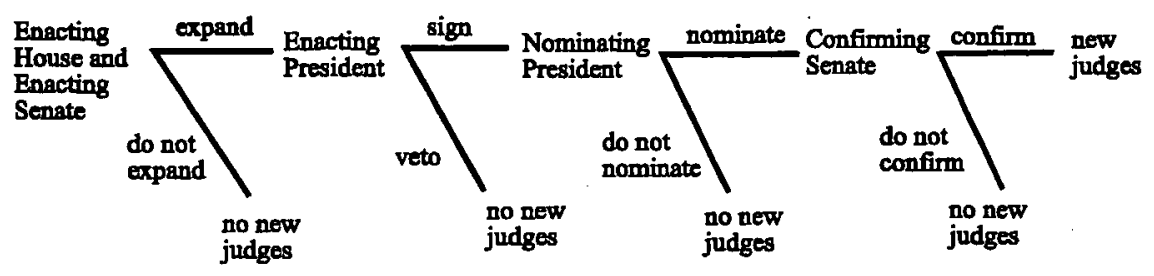

Figure 3.-Expansion process

that requests by the judiciary for more judgeships has minimal effect on the timing and size of expansion. We will show, however, that political alignment plays the more critical role.

\section{The TIming of Judicial Expansion}

\section{A. The Alignment Model}

We model the expansion process as a simple game involving five actors which plays out over four stages. Figure 3 illustrates the sequence and possible outcomes. The relevant actors are the enacting House, enacting Senate, enacting president, nominating president, and the confirming Senate. ${ }^{20}$ In the first stage the enacting House and the enacting Senate both must decide whether to pass expansion legislation creating new judgeships. If the enacting chambers both vote to expand, then a second stage occurs where the enacting president signs or vetoes the bill. If the expansion bill is passed and signed, the nominating president either nominates or does not nominate judges to the newly created judgeship. ${ }^{21}$ If the nominating president nominates, then the confirming Senate either confirms or rejects the nominee in the fourth and final stage. ${ }^{22}$

We assume that each actor prefers judges from its own party over no new judges and no new judges over judges of an opposing political party. Thus, an enacting House, Senate, and president should vote to expand only when they expect the nominating president and the confirming Senate to appoint and approve judges of the enacting House, Senate, and president's party.

${ }^{20}$ The distinction between enacting institutions and postenacting institutions is not trivial, as expansions have occasionally crossed congressional or presidential tenures.

${ }^{21}$ To not make a nomination is equivalent to retaining a vacancy.

${ }^{22}$ For a political bargaining model of appointments, as it applies to regulatory agencies, consider Susan Snyder \& Barry R. Weingast, The American System of Shared Powers: The President, Congress, and the NLRB (unpublished manuscript, Stanford Univ., July 1994). 
As the nominating president and confirming Senate will only nominate and confirm judges from their own respective parties it becomes immediately clear that there will be a new judge in a new judgeship on the bench only if all five institutions are aligned. Accordingly, that all five institutions be politically aligned is a necessary condition for the passage of legislation expanding the size of the judiciary. ${ }^{23}$

\section{B. Predictions and Data}

The model predicts that all five institutions must be held by the same political party before expansion occurs. In order to test the model, we examine as our dependent variable whether or not there has been a judicial expansion of the Supreme Court and the Federal Circuit Appellate Courts of the United States. We define an expansion as an increase in the number of permanent judgeships authorized by Congress during a 2-year congressional session. ${ }^{24}$ All time periods since the founding of the United States are considered.

We obtained data on judicial expansion from the Federal Judicial Center's History of the Authorization of Federal Judgeships Including Procedures and Standards Used in Conducting Judgeships Surveys. ${ }^{25}$ This source also provided detailed information about the precise date and statute under which the judgeships were authorized. In cases where the expansion authorization was between a regularly scheduled election and the inauguration of a new congress, the date of judicial confirmation and swearing in of political officials was used to determine the political affiliation of the nominating president and the confirming Senate.$^{26}$ Where required, the narrative history of each court of appeals was consulted. ${ }^{27}$

${ }^{23}$ In order to overcome indifference points, we employ the additional assumption that it is costly for the enacting House and Senate to pass expansion legislation (and consequently would not do so unless they expected the eventual appointment of a politically aligned judge). Similar cost assumptions can be made to overcome any indifference points of the remaining players.

${ }^{24}$ In this test, we have not included senior judgeships, visiting judgeships, temporary judgeships, or judgeships on the recently created Federal Circuit Court of Appeals.

${ }^{25}$ Federal Judicial Center, supra note 14.

${ }^{26}$ Such expansions occurred often between 1887 and 1929. See 24 Stat. 492 (1887), 26 Stat. 826 (1891), 27 Stat. 434 (1893), 28 Stat. 643 (1895), 28 Stat. 665 (1895), 30 Stat. 846 (1899), 30 Stat. 803 (1899), 32 Stat. 791 (1903), 33 Stat. 611 (1905), 33 Stat. 992 (1905), 43 Stat. 1116 (1925), 45 Stat. 1081 (1929), 45 Stat. 1346 (1929), 45 Stat. 1414 (1929).

${ }^{27}$ Harold Chase, Samuel Krislov, Keith Boyum, \& Jerry Clark, Biographical Dictionary of the Federal Judiciary (1976). The judgeship data were cross-checked with the relevant information in Posner, supra note 18, at app. B. 
TABLE 2

Political Alignment during Years of Expansion and Contraction FOR THE SUPREME COURT, 1789-1869

\begin{tabular}{lcccccc}
\hline \hline Year & Congress & $\begin{array}{c}\text { No. of } \\
\text { Additional } \\
\text { Judgeships }\end{array}$ & $\begin{array}{c}\text { Total } \\
\text { Judgeships }\end{array}$ & $\begin{array}{c}\text { House } \\
\text { Majority } \\
\text { Party* }\end{array}$ & $\begin{array}{c}\text { Senate } \\
\text { Majority } \\
\text { Party }\end{array}$ & $\begin{array}{c}\text { Presidential } \\
\text { Party }\end{array}$ \\
\hline 1789 & Creation & 6 & 6 & F & F & F \\
1801 & 10 & 1 & 7 & DR & DR & DR \\
1837 & 25 & 2 & 9 & D & D & D \\
1864 & 38 & 1 & 10 & R & R & R \\
1869 & 41 & -1 & 9 & R & R & R \\
\hline
\end{tabular}

*The parties are coded as follows: $F=$ Federalist, $D R=$ Democratic-Republicans, $D=$ Democrat, $\mathbf{R}=$ Republican .

\section{The Supreme Court}

The Supreme Court was established in 1789. Congress set the original number of justices at six. ${ }^{28}$ Between 1789 and 1869 Congress changed the size of the Court four times (three expansions and one contraction) before finally settling on nine justice positions. ${ }^{29}$ These are documented in Table 2. The three expansions of the Supreme Court are consistent with the predictions of the model as all expansions occurred during political alignment. ${ }^{30}$ However, given the large number of political alignments between 1789 and 1869 ( 31 of 40 congresses) and the relatively few number of Supreme Court expansions, there is insufficient variance in the data to yield definitive results. ${ }^{31}$

${ }^{28}$ The Supreme Court was created in 1789 by constitutional mandate and not by the legislative model described above. Accordingly, we do not include the creation of the Supreme Court as an expansion observation.

29 The one contraction of the Supreme Court in 1869 eliminated a vacant seat.

${ }^{30}$ Notwithstanding the act of 1802 , the ability of Congress to contract the size of the judiciary appears limited. The Constitution states that a federal judge is entitled to hold office during good behavior. Eliminating a judgeship while it is occupied appears to work against this principle. Congress did not again abolish a court until 1913 when it terminated the Commerce Court. The sitting judges, however, were redistributed among the circuit courts. See The Constitution of the United States: Analysis and Interpretation (Johnny H. Killian \& Leland E. Beck eds. 1982) for a discussion of the contraction issue.

31 The threatened Supreme Court packing plan of the Roosevelt administration in 1937 is also consistent with the hypotheses of the model. Because of political alignment of the House, Senate, and president, the Roosevelt administration's threat to expand the Supreme Court, in our view, was a credible one. Gely and Spiller demonstrate that the Supreme Court did change its voting patterns in response to these threats by the Roosevelt administration. Rafael Gely \& Pablo T. Spiller, The Political Economy of Supreme Court Constitutional Decisions: The Case of Roosevelt's Court-Packing Plan, 12 Int'l Rev. L. \& Econ. 45 (1992). 


\section{The Federal Courts of Appeal}

Given the more numerous expansions in the federal appellate court, along with the higher variance in the underlying political alignment of the two chambers of Congress and the president, we opted to use appellate court expansion data to test our model against the caseloads explanation. Between 1869 and 1991, there have been 36 statutes passed in 30 different years to expand the appellate courts. ${ }^{32}$ These expansions have occurred in 25 different congresses. Table 3 identifies each expansion and reviews the political makeup of both chambers of Congress and the executive branch. ${ }^{33}$ The alignment and expansion totals are set out in Table 4. In 21 of 25 cases (84 percent) of judicial expansion in the appellate courts, there has been political alignment among the House, Senate, and president. This result broadly conforms to the predictions of the model. We expect to see alignment between the legislature and the executive in most cases of appellate court expansion. The underlying incidence of alignment during the 1869 to 1991 period is 59 percent which, using a $\chi^{2}$ test, allows us to reject the hypothesis that expansion is independent of alignment at the 99 percent level..$^{34}$

The Econometric Model. We now conduct a multivariate test which allows us to test the political efficiency theory while allowing other independent variables to be considered. Specifically, we wish to test our explanation for judicial expansion against the "institutional efficiency" story which predicts that caseload pressure drives the timing of judicial expansion.

We let $y^{*}=X_{i} \beta+\mu_{i}$, where $y^{*}$ is a latent variable reflecting the decision to expand. Thus, expansion takes place if $y^{*}>0$ and does not if $y^{*} \leq 0$. Assuming the standard normality assumption for $\mu_{i}$, we have the traditional probit model where the probability of an expansion is given by the probability that $\mu_{i}>-X_{i} \beta_{i}$, determined by $F(X \beta)$, where $F$ is the cumulative normal distribution function. Our unit of observation is the 2-year congressional session ( $n=61$ between 1869 and 1991). Note that if a particular congress passed more than one expansion, it still receives only one data point. ${ }^{35}$

${ }^{32}$ The aforementioned acts in 1801 and 1802 are not considered in the subsequent econometric analysis.

${ }^{33}$ This fully characterizes the nominating president and confirming Senate as well, except in 1893 where the nominating president and the confirming Senate are both under Democrat control.

${ }^{34}$ We use a $\chi^{2}$ to test the following hypothesis: $\mathrm{H}_{0}: \pi_{i j}=\pi_{i} \pi_{j}$, and $\mathrm{H}_{1}: \pi_{i j} \neq \pi_{i} \pi_{j}$, where $\pi_{i j}$ denotes the underlying bivariate probability distribution derived from the frequencies listed in Table 4. The table considers the 61 congresses from 1869 to 1991.

${ }^{35}$ The rationale for treating the data in this way is that the institutional alignment of the actors does not change within' a congressional period. 


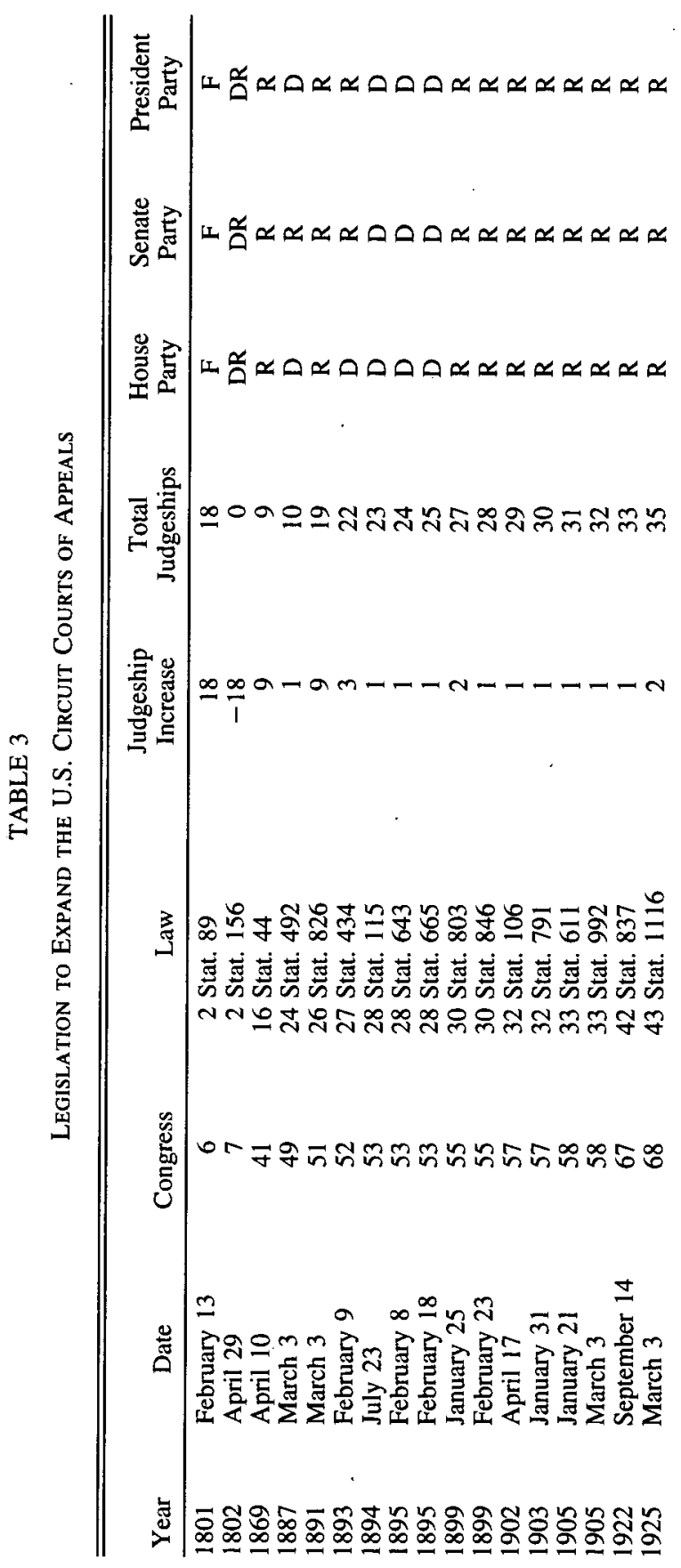




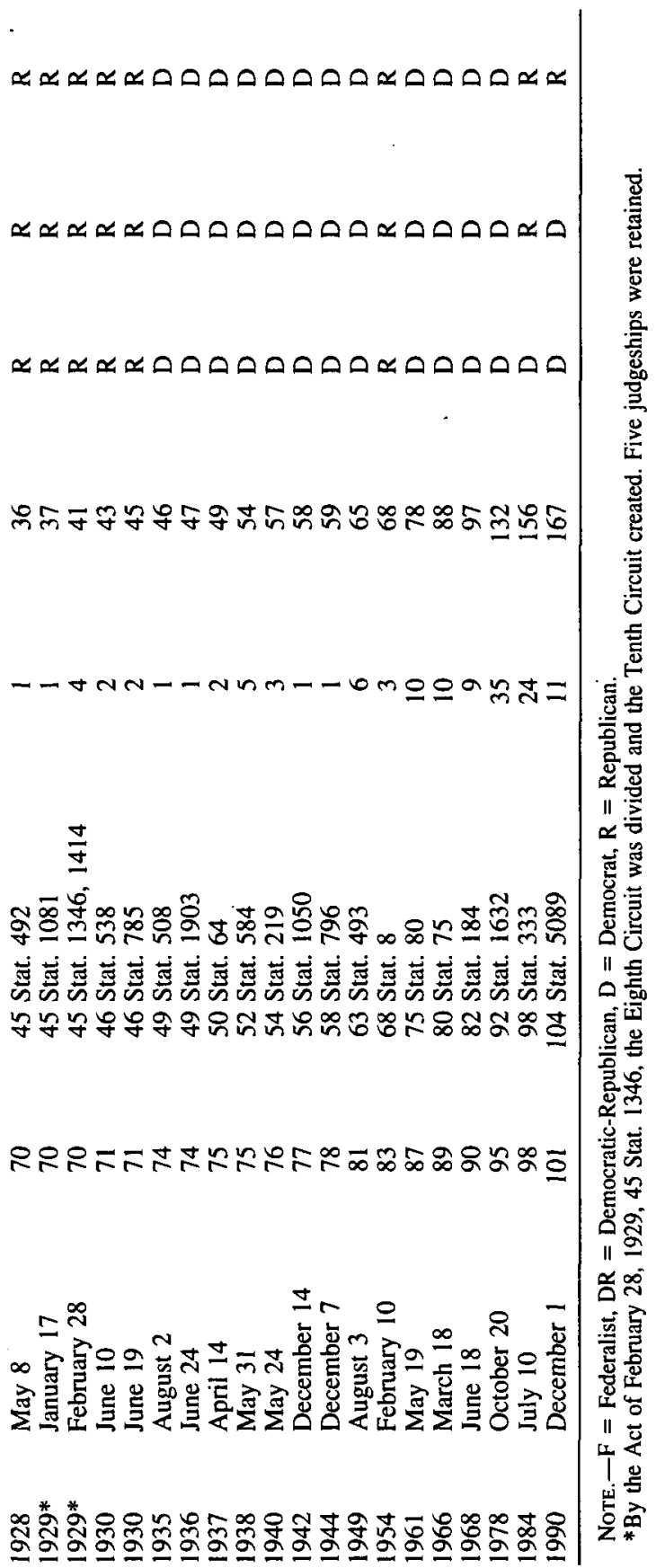


TABLE 4

Political Alignments and Judicial Expansions

\begin{tabular}{|c|c|c|c|c|}
\hline & \multicolumn{3}{|c|}{ JUDICIAL EXPANSION } \\
\hline & & YES & No & Total \\
\hline \multirow{3}{*}{$\begin{array}{l}\text { POLITICAL } \\
\text { ALIGNMENT }\end{array}$} & YeS & 2 I & 15 & 36 \\
\hline & No & 4 & $2 I$ & 25 \\
\hline & Total & 25 & 36 & $6 I$ \\
\hline
\end{tabular}

The first independent variable of interest is CASELOAD PER JUDGE, which is the number of cases per judge pending on the docket (in hundreds) in the preceding time period. ${ }^{36}$ Because appellate court caseload records are kept only from 1892 to the present, we estimated appellate caseload data for 1868 to $1892 .{ }^{37}$ Next, we introduce two control variables. ${ }^{38}$ The first control variable, TIME, measures the amount of time (in congressional periods) since the last expansion. This variable controls for trend effects. The second

${ }^{36}$ We used a variety of measures for caseload and obtained similar results to the ones reported here.

37 To do the estimation we began with available data on the district courts. Full civil district court caseload data were available for all years after 1876. For district court caseload, we obtained a summary report of the Reports of the Attorney General from 1871 to 1934 where the statistics are compiled with the best data possible. The American Law Institute, A Study of the Business of the Federal Courts (pt. 2) 19-21, detailed table 1 (May 10, 1934); and Annual Reports of the Attorney General (1872-94). For 1871-75, the attorney general of the United States kept records of U.S. civil cases pending in district court. Using later years as a benchmark (1876-1907) we calculated that civil cases represented approximately 33 percent of all cases in the district courts. From there, we could estimate the full caseload for 1871-75. Using an ordinary least squares regression, we then calculated the trend of caseload increase for 1871-92 and used these data to interpolate backward to obtain an estimate of full district court caseload for 1868-70. This procedure gave us the district court caseload data for 1868-92.

Having established numbers for district court caseload, we then proceeded to estimate appellate court caseload data for 1868-91. Using known appellate caseload data from 1892 to 1907, we calculated the percentage of cases appealed from the district courts to the appellate courts as 2.15 percent. We note that during the $1892-1907$ period, the mean was 2.15 percent, the median 2.10 percent, and the range $1.5-2.8$ percent. We then multiplied 2.15 percent times the district court caseload data to obtain an estimate for the court of appeals caseload for 1868-92. This gave us our caseload data for the appellate courts. Selected estimates were then cross-checked against Supreme Court data for consistency. During the 1892-1907 time period, approximately 50 percent of cases from the circuit appeals courts were appealed to the Supreme Court annually. Id., Annual Reports. Knowing the Supreme Court filings for 1868-92, we found that our estimated appellate court data were consistent with the 50 percent rate of appeals to the Supreme Court.

${ }^{38}$ Unfortunately, we are unable to test judicial requests for judgeships in this econometric test because systematic, analytic, and formal requests from the Judicial Conference began only in 1964 . 
control variable is BUDGET GROWTH, which measures the percentage growth of the nondefense, noninterest payment, portion of the federal budget. ${ }^{39}$ As the United States's budget grows, one might expect funding for new judgeships to keep pace. ${ }^{40}$

Finally, we have POLITICAL ALIGNMENT, which is a dummy variable equal to one if there is political alignment among the five actors (enacting House, Senate, and president and the nominating president and confirming Senate), and zero if any of those actors is of a different party than the others. A positive coefficient of this variable indicates that political alignment increases the probability of a judicial expansion. To determine the political alignments by congressional session, we used Congressional Quarterly's Annual Almanac.

Results of the Probit Analysis. Table 5 provides the results of the probit estimation procedure that predicts the probability of a judicial expansion. The standard errors are in parenthesis below the estimated coefficients. TIMING MODEL 1 is the baseline model which examines the power of the nonpolitical explanations for judicial expansion. In TIMING MODEL 2, the POLITICAL ALIGNMENT variable is included. A log-likelihood ratio test

${ }^{39}$ Data on gross national product and federal budget surplus of the United States were obtained from the Statistical Abstract of the United States and the Historical Abstract of the United States.

${ }^{40}$ Two other variables have been suggested for consideration: salaries of judges and U.S. territorial expansion. With respect to salaries, there are several possible effects. First, from an institutional efficiency perspective, salaries and expansion may be substitutes such that rising caseload may result in either expansion or increased salaries (or even staff budgets). If this is so, then caseload is having a stronger effect on congressional decision making than our model suggests. From a political efficiency perspective, salaries and expansions may again be substitutes. If Congress is unhappy with the courts, it can refuse to increase salaries, or it can change the mixture of personnel through expansion. See Eugena F. Toma, Congressional Influence and the Supreme Court: The Budget as a Signaling Device, $20 \mathrm{~J}$. Legal Stud. 131 (January 1991). While we think that salaries (or judicial budgets) may have a disciplining effect, we believe that its effect is more fleeting, as the threat of the purse can change from congress to congress. Judicial expansion, however, can perpetuate a particular congress' ideology long after that congress has passed as it would take another fully aligned congress and president to instigate another expansion. Nonetheless, we run salary data in our model to check for their effects. See note 43 infra.

The second suggested variable is U.S. territorial expansion. During the latter part of the 1800 s and early part of the 1900 s, many states were added to the United States. One might expect that this increased the need for judges. We do not believe this is the case because, as early as 1868, appeals from the territories were being heard in the circuit courts. By the time the appeals courts became active, all of the area that represents the states of the U.S. were already under appellate jurisdiction. See Surrency, supra note 6. Additional permanent U.S. territorial expansion since 1870 (for example, Micronesia, Samoa, etc.) represents in population and area less than a 1 percent increase to the United States. The Philippines, which was a U.S. territory from 1898 to 1946 , not included in the 1 percent figure, itself represents less than a 3 percent increase in U.S. territory. These territorial expansions were not included in the statistical analysis. 
TABLE 5

Results of Probit ANalysis for Judicial Expansion OF THE Federal Appellate Court, 1869-1991 Dependent Variable: Expansion of Judiciary $=1$; No Expansion of Judiciary $=0$

\begin{tabular}{lcc}
\hline \hline Independent Variable & TIMING & TIMING \\
MODEL 1 & MODEL 2 \\
\hline CONSTANT & -.0975 & $-1.8483^{* * *}$ \\
& $(.3492)$ & $(.6640)$ \\
CASELOAD PER JUDGE & .0280 & .6669 \\
& $(.3328)$ & $(.4098)$ \\
TIME & -.0485 & .0433 \\
& $(.0792)$ & $(.0925)$ \\
BUDGET GROWTH & -.1035 & -.1573 \\
& $(.1844)$ & $(.1680)$ \\
POLITICAL ALIGNMENT & $\ldots$. & $1.6293^{* * *}$ \\
& & $(.4684)$ \\
Log likelihood & -40.79 & -33.36 \\
No. of observations & 61 & 61 \\
\hline
\end{tabular}

NoTE.-Standard errors are in parentheses.

***Significant at the $1 \%$ level.

indicates that we can reject the hypothesis that the two models have equivalent explanatory power at the 95 percent level. TIMING MODEL 2 is a significant improvement on TIMING MODEL 1. Note that in TIMING MODEL 1 , not a single variable is significant. The estimation procedure selects zero as its maximum likelihood estimator for all observations and gets 59 percent of the observations correct.

As predicted, the coefficient of POLITICAL ALIGNMENT is positive and significant at the 99 percent level. Indeed, political alignment increases the probability of judicial expansion by 53 percent from the mean value of the independent variables. This result indicates that the timing of judicial expansion is directly and significantly affected by political alignment. ${ }^{41}$ Moreover, the model with political alignment (TIMING MODEL 2) correctly predicts the dependent variable 69 percent of the time, compared with 59 percent in TIMING MODEL 1. Put differently, in TIMING MODEL 2 there is approximately a 25 percent decrease in incorrect predictions of expansion over TIMING MODEL 1, which does not consider political alignment.

${ }^{41}$ Since 1869 , there have been 10 uninterrupted periods of political alignment. In nine of these 10 , judicial expansion has been authorized by Congress. The only period of continuous alignment when there has not been expansion occurred during World War I. If each block of alignment is considered an opportunity to expand, then Congress expanded the judiciary in nine of 10 opportunities. 
Now consider the variable CASELOAD PER JUDGE. The coefficient of this variable is not significant, which indicates that caseloads do not have great explanatory power when it comes to the timing of judicial expansion. We repeated both TIMING MODEL 1 and TIMING MODEL 2 for a variety of different measurements of caseload and obtained similar results. The two control variables, TIME and BUDGET GROWTH, are both negative and insignificant in each specification of the model. The standard errors are large enough that not much can be made of their signs. One interpretation of the insignificant BUDGET GROWTH could be that the government expands the judiciary without reference to the larger federal budget. ${ }^{42} \mathrm{Simi}$ larly, the TIME variable is not an important factor. ${ }^{43}$

\section{The Size of Judicial Expansion}

Having addressed the timing of judicial expansion, we now consider how Congress determines the size of expansion once it has agreed to undertake an expansion. We argue that both political efficiency (political alignment) and institutional efficiency (caseload pressure) determine the number of judgeships a congress will authorize. As with our first model, we test this hypothesis using an econometric test.

\section{A. The Model}

Consider a congressional and presidential joint utility function in the expansion decision. For ease of exposition, we will refer to this as the con-

${ }^{42}$ For example, during the Depression, the Vietnam War, and the $1980 \mathrm{~s}$, three periods of substantial federal government deficit spending, significant judicial expansions were authorized by the Congress.

${ }_{43}$ Toma, supra note 40 , suggests that Congress uses its budgeting power to influence decision making on the Supreme Court. She argues that Congress cuts budget allocations to the judiciary when judicial decisions are contrary to the ideology of Congress. Moreover, she finds this disciplining device causes justices to change their decisions to accommodate Congress. To examine this within the current context, we include a variable that measures judicial salaries. This variable measures the percentage differential between changes in Cabinet officers' salaries and appellate court judges' salaries from 1869 to 1991 . We lagged this variable one time period. The reasoning here is that, when Congress wishes to discipline the judiciary, it cuts the salaries of justices (relative to those of Cabinet officers). If this is ineffective as a disciplining device, then the Congress must expand the court. Thus we would expect a negative coefficient on the JUDGE SALARY variable. A salary cut in the last period increases the probability of an expansion. Alternatively, as Toma suggests, if salary cuts are effective, then we would expect a positive coefficient on the JUDGE SALARY variable. A salary cut in the last period means that the justices have been disciplined and, thus, decreases the probability of an expansion in this period.

When we include the JUDGE SALARY variable in the probit analysis, we obtain a positive coefficient (1.0066) for the variable which supports the Toma hypothesis. However, this coefficient is insignificant $(S E=1.3584)$. The remainder of the results in both the probit and ordinary least squares remain approximately the same. 
gressional utility function and consider the maximization problem for $\mathrm{Re}$ publicans. ${ }^{44}$ We define the benefit function as

$$
B\left(\frac{R+\Delta N j_{r}}{N+\Delta N}, \frac{N+\Delta N}{c}\right),
$$

where $N$ is the number of judgeships that exist before the expansion, $R$ is the number of Republican judges occupying existing judgeships, $\Delta N$ is the number of additional judgeships that are created in an expansion, and $j_{r}$ is a dummy variable which is equal to one if there is Republican alignment and zero otherwise. Finally, $c$ is the caseload that the judiciary faces. ${ }^{45}$

The first term of the benefit function represents the political effect of expansion. It indicates that Republicans are concerned with the number of Republican-minded judges on the bench. We let $\partial B / \partial 1=B_{1}>0$ and $\partial^{2} B /$ $\partial 1 \partial 1=B_{11}<0$, where 1 represents the first term of the benefit function. ${ }^{46}$ The Republicans wish to place as many Republican judges as possible on the bench given that marginal utility is diminishing. The second term of the benefit function suggests that the utility of Congress in determining the number of judges is affected by the caseload per judge. We let $\partial B / \partial 2=$ $B_{2}>0$ and $\partial^{2} B / \partial 2 \partial 2=B_{22}<0$, where 2 represents the second term of the benefit function. This means that Congress receives a benefit from attending to the institutional efficiency of the court with diminishing marginal utility.

We assume that there is a cost for legislators to expand the judiciary. The cost, $C(N+\Delta N)$, is a function of the number of judgeships in the expansion. We will also assume for simplicity that marginal cost is positive and constant, that is, $C^{\prime}(\Delta N)>0, C^{\prime \prime}(\Delta N)=0 .{ }^{47}$

Utility is defined as $U(\cdot)=B(\cdot)-C(\cdot)$. When deciding how much to expand the judiciary, Congress meets the traditional utility-maximizing requirement of setting the marginal benefit (MB) of an expansion equal to the marginal cost (MC). The first-order condition of the utility maximization problem with respect to $\Delta N$ is

44 A similar utility function would exist for Democrats.

${ }^{45}$ Disequilibrium conditions may arise (that warrant the creation of new judgeships, $\Delta N$ ) because of new elections, changes in preferences, or underlying changes in the makeup of the judiciary through new appointments or retirements.

${ }^{46}$ For simplicity, we assume cross-partial derivatives are equal to zero, although this assumption can be relaxed without significantly altering our results.

${ }^{47}$ The results hold for $C^{\prime \prime}(\Delta N)>0$ and for small values of $C^{\prime \prime}(\Delta N)<0$. 


$$
\partial U / \partial \Delta N=B_{1}(\cdot)\left[\frac{N}{N+\Delta N}\right]\left[\frac{j_{r}-\frac{R}{N}}{N+\Delta N}\right]+\left[\frac{B_{2}(\cdot)}{c}\right]-C^{\prime}(\Delta N)=0 .
$$

From the model we can derive two primary results. First, the utility maximizing number of new judgeships for Congress, $\Delta N^{*}$, is that point where $\mathrm{MB}=\mathrm{MC}$ and yields a solution $\Delta N^{*}\left(N, R, j_{r}, c\right)$. This indicates that both politics and caseload will determine $\Delta N^{*}$. Second, the number of judgeships allocated under alignment will be higher than the number allocated under nonalignment, should a nonaligned expansion occur. If there is political alignment, both terms of the MB (the first two terms of the above equation) will be positive, whereas if there is no alignment, $j_{r}$ will be zero and $j_{r}-R / N$ will be negative. This means that the benefit function of an aligned congress lies strictly above the benefit function of a nonaligned congress for any $\Delta N$. A utility-maximizing Congress that sets $\mathrm{MB}=\mathrm{MC}$ will create a smaller number of new judgeships under nonalignment than it will under alignment. ${ }^{48}$ Relatedly, if there is no alignment, then the utility that Congress attaches to lowering caseload must be very large for an expansion to occur. In order to obtain some positive marginal benefit, the positive magnitude of the second term must be larger than the negative magnitude of the first term. This will occur only if $B_{2}(\cdot)$ is positive and very large for a given $c$, which results only if Congress attaches significant weight to institutional efficiency. ${ }^{49}$

\section{B. An Empirical Test}

\section{The Econometric Specification}

In order to test these two hypotheses, we employ a two-step estimator of the determinants of expansion. The first step is the probit reported in the previous section. The second step is a regression including only the $25 \mathrm{in}$ stances of expansion, correcting for sample selection (using the Heckman correction).$^{50}$ The model suggests that, when MB and MC cross, expansion

${ }^{48}$ If $j_{r}=0$, then the first-order condition reduces to $B_{2} / c-C^{\prime}(\Delta N)=B_{1} R /(N+\Delta N)^{2}$. If, however, there is political alignment and $j_{r}=1$, then the first-order condition reduces to $B_{2} / c-C^{\prime}(\Delta N)=-B_{1}(N-R) /(N+\Delta N)^{2}$, which results in more new judgeships than under a strict institutional efficiency story (where $j_{r}=0$ ).

${ }^{49} \mathrm{We}$ argue in Section III above that this is not normally the case. Thus political alignment will be necessary for expansion.

so The ratio of the estimated value $\phi_{i} /\left(1-\Phi_{i}\right)$ is the inverse Mills ratio and is saved from the probit TIMING MODEL 2 for inclusion in this econometric specification. We follow the methodology proposed by G. S. Maddala, Limited-Dependent and Qualitative Variables in Econometrics (1983); and R. B. Roberts, G. S. Maddala, \& Gregory Enholm, Determinants 
will occur. Otherwise, we do not expect to see expansion. Moreover, when they do cross, the judicial expansion is given by

$$
w_{i}=\gamma^{\prime} Z_{i}+\epsilon_{i}
$$

where $w_{i}$ is the size of the expansion and $Z_{i}$ is the vector of independent variables that determine the number of judges in an expansion. The probability that MB and MC cross was already modeled in Section III as a probit formulation, with the probability of expansion given by $\Phi(X \beta)$. If shocks to the decision to expand and to the decision of how much to expand are correlated, then $E(\epsilon) \neq 0$. In such case, Heckman's two-stage correction is necessary. All standard errors are corrected for heteroscedasticity and are adjusted so that they are consistent.

\section{The Data}

In this model, the dependent variable is ADDED JUDGESHIPS, which is defined as the number of additional judgeships authorized in a congress for those 25 observations where expansion is positive. The two primary variables of interest are CASELOAD GROWTH and POLITICAL ALIGNMENT. CASELOAD GROWTH measures the change in cases (in hundreds) since the last expansion. POLITICAL ALIGNMENT is defined as before. The econometric test examines whether political alignment and caseload growth have an effect on the number of new judgeships created, conditioned on an expansion occurring. The model predicts that both of these variables should have positive coefficients. We let MILLS represent the inverse Mills ratio as defined in the Heckman correction to the econometric specification above.

The model suggests that the current ideological makeup of the judiciary might have a bearing on the expansion decision. Specifically, the larger the surplus of judges from the opposing party, the larger the incentive of an aligned congress to install many of their own judges to dilute the current judicial ideology. Thus, Congress will vote for a larger expansion. In contrast, if the members of the judiciary are of the same political ideology as the aligned Congress and president, then the utility of adding many new judges is greatly reduced. In order to control for this effect we introduce a variable called JUDICIAL MAKEUP. This variable is a count variable and measures the number of consecutive congressional periods that the presidency is held by one party. It resets to one in the Congress in which there

of the Requested Rate of Return and the Rate of Return Granted in a Formal Regulatory Process, 9 Bell J. Econ. 611 (Autumn 1978). 
TABLE 6

Results of a Two-Step ANalysis for Number of AdDitional JUDGESHIPS IN JUDICIAL EXPANSION OF THE FEDERAL APPEllate Court, 1869-1991

Dependent Variable: ADDED JUDGESHIPS

(Number of Additional Appellate Judgeships)

\begin{tabular}{lcc}
\hline \hline & $\begin{array}{c}\text { SIZE } \\
\text { Independent Variable }\end{array}$ & $\begin{array}{c}\text { SIZE } \\
\text { MODEL 2 }\end{array}$ \\
\hline CONSTANT & -23.7697 & $-21.8169^{*}$ \\
& $(14.5687)$ & $(12.8444)$ \\
CASELOAD GROWTH & $.2982^{* * *}$ & $.2940^{* * *}$ \\
& $(.0590)$ & $(.0529)$ \\
POLITICAL ALIGNMENT & $18.9148^{* *}$ & $18.5765^{* *}$ \\
& $(9.1645)$ & $(7.9689)$ \\
MILLS & 12.9670 & $12.8434^{*}$ \\
& $(7.9194)$ & $(7.04112)$ \\
JUDICIAL MAKEUP & & -.4290 \\
& & $(.4125)$ \\
Adjusted $R^{2}$ & .7820 & .7862 \\
$F$-statistic & 29.69 & 23.06 \\
\hline
\end{tabular}

NOTE.-All standard errors are heteroscedastistic-consistent estimates and are in parentheses.

* Significant at the $10 \%$ level.

** Significant at the $5 \%$ level.

*** Significant at the $1 \%$ level.

is a shift of party of the presidency. ${ }^{51}$ We would expect that the longer a party holds the presidency, the lesser the need to pack the judiciary with expansion judges. This is because the president would already have had time, through natural attrition, to appoint judges of his own party to the judiciary. ${ }^{52}$ Thus, we would expect the coefficient on this variable to be negative.

\section{Results of the Two-Step Regression Analysis}

Table 6 shows the results. ADDED JUDGESHIPS is the dependent variable. SIZE MODEL 1 is the baseline model where the main hypotheses are tested. Note that both the caseload and political alignment variables are sig-

51 For example, when President Reagan took office, the variable started counting at one. By 1988, the variable had reached a value of four to represent the four congresses over which Reagan held the Presidency. When Bush came to power in 1989, the variable went to five because Bush was of the same party as Reagan. It counted to six to represent the two congresses that Bush's term as president spanned and the six congresses that Republicans spanned. When Clinton took office in 1993, the variable reset to one.

52 Recall that Zuk, Gryski, \& Barrow, supra note 11, have shown that presidents appoint judges of their own party with a 93 percent confirmation rate. 
nificant at the standard levels of confidence. The coefficient of CASELOAD GROWTH is, as hypothesized, positive. This would indicate that change in caseload is indeed an important determinant of the size of a judicial expansion. The coefficient of POLITICAL ALIGNMENT in the baseline model is also positive, implying that political alignment has a positive effect on the number of judges if an expansion takes place. Recall that the caseload variable is a measure of hundreds of cases. Given the size of the estimated coefficients, we can calculate the comparative effect of caseloads and politi$\mathrm{cal}$ alignment. We find that a change of 6,500 cases since the last expansion has roughly the same effect as political alignment in obtaining additional judges. This level of caseload increase does not occur in the history of the United States until the 1980s.

In the more fully specified SIZE MODEL 2, we include a measure for the current makeup of the judiciary. The positive and significant coefficient on MILLS suggests a positive covariance between the errors of the probability and size of expansion. The coefficient of JUDICIAL MAKEUP is negative, as expected, but not significant. ${ }^{53}$ The significance and magnitude of the coefficients on the remaining variables do not change appreciably between the two models. The results support our hypothesis that political alignment and caseload are decisive factors.

Figure 4 illustrates the predictive power of the model. We compare the number of judgeships predicted by SIZE MODEL 1 (which is almost identical to the number predicted by SIZE MODEL 2) to the actual number of judgeships authorized by Congress in each expansion period. As can be seen, the model tracks the actual number of judges quite well. Only in the 1890s does the model systematically overpredict the number of judgeships authorized. ${ }^{54}$ By the time of the New Deal, new judgeships are, on average, tracked quite well.

${ }^{53}$ The insignificance may be due to the crudeness of our measure. A more precise measure, such as the actual political affiliation of each judge during each year, may yield more definitive results.

${ }^{54}$ One alternative theoretical argument that has been made is that the size or stability of the political alignment will determine the number of judgeships approved. If a party has a large majority, then it is unlikely, barring any extraordinary event (for example, the Depression), that the party will be ousted from power. In these cases, the Congress might increase the number of judges incrementally, in small numbers, in each successive congress. Alternatively, if the Congress lies in precarious alignment where majorities are small and unstable, then an aligned congress has the incentive to expand the judiciary substantially.

In order to test this hypothesis, we examined the size of the majority party held in the House and in the Senate. If the above hypothesis is true, then the number of additional judgeships should be a decreasing function of the size of the majority. While in the case of the House this is true, it is not the case in the Senate. However, the coefficients are small and insignificant in both cases.

A second argument is that caseload per judge needs to be controlled. That is, technology has allowed a higher caseload per judge. We examine this widely held notion on two levels. First, we examine the data and find that the increasing caseload per judge is really just a 


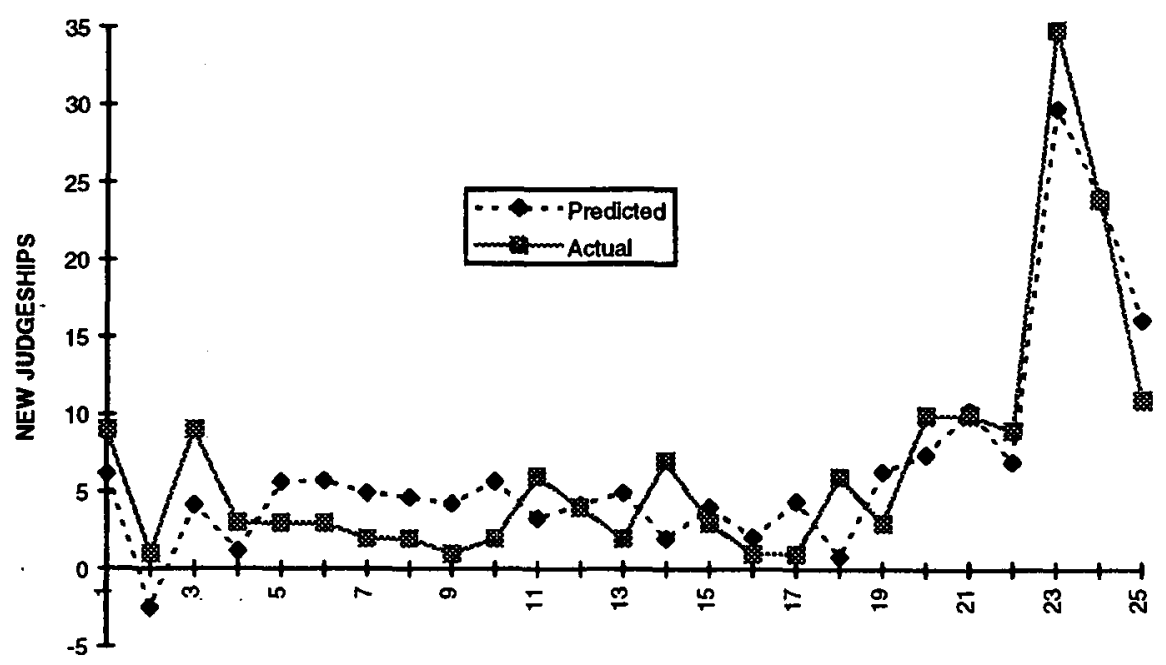

EXPANSION NUMBER

FIGURE 4.-Actual and predicted number of new judgeships authorized by Congress

\section{Conclusion}

Installing like-minded judges relieves Congress of the need to monitor and discipline the judiciary as such judges would be expected to share a common sense of justice with the legislators. Congress could rely on the judiciary to arrive at the "right" decisions rather than having to override judicial decisions with time-consuming legislation. Expanding the judiciary facilitates this effect by allowing Congress to selectively allocate judgeships to fit its own liking (rather than patiently waiting for judicial retirements).

phenomenon of recent times. For the first 100 years of the Court, the caseload per judge wandered between 30 and 100 in any given year. It is not until the late 1960 s that the number of cases per judge began to exceed 100 . Thus, it is not surprising that a coefficient on a trend variable is insignificant during the time period.

Although the technology hypothesis does not seem to bear on the data analysis, it does point to a possible specification problem for the econometrics. Given the precipitous rise in caseload per judge beginning in the mid-1960s, are we witnessing a different model of expansion in the final observations? That is, is there one model of expansion from 1870 to 1965 and another from 1965 to the present? Given the small number of observations, we expect some instability in the coefficients. However, is there sufficient instability to assume that two different models are operative?

In order to test for the stability of coefficients, we conducted a Chow prediction test on the sum of squared residuals as specified by William H. Greene, Econometric Analysis (1992). This test is particularly useful when there are inadequate degrees of freedom to conduct the more common Chow test on subsamples. We find that we cannot reject the hypothesis that the coefficients are stable at the 95 percent level of confidence. An alternative decision-making pattern does not seem to have been operating since the 1960 s. 
We argued that, as Congress seeks to maximize this political efficiency, it will be more inclined to pass judicial expansion legislation during periods of political alignment (alignment among the enacting House, Senate, and president and the nominating president and confirming Senate) than during periods of nonalignment. We found that in 100 percent of the Supreme Court expansions and 84 percent of the appellate court expansions our political efficiency model was supported. The econometric test further supported our model as we found that, when compared with caseload pressure, political alignment was the most important determinant in deciding when an expansion would occur. We also considered the size of expansion and found that the data support our hypothesis that Congress considers both institutional efficiency (changing caseload) and political efficiency in determining the number of judgeships it will grant in an expansion.

While we have attempted an in-depth analysis of judicial expansion, several important questions remain. Does the alignment effect apply to the expansion of lower federal district court judgeships? Does the current political makeup of the judiciary play a more important role than indicated in our analysis here? Does the political efficiency theory apply to the states, where judges may come to the bench in ways different from those of the federal courts (such as election)? We leave these questions for future research.

\section{BIBLIOGRAPHY}

American Law Institute. A Study of the Business of the Federal Courts, Pt. 2. Philadelphia: American Law Institute, May 10, 1934.

Baker, Thomas E. "An Assessment of Past Extramural Reforms of the U.S. Courts of Appeals." Georgia Law Review 28 (1994): 863-912.

Barrow, Deborah J., and Zuk, Gary. "An Institutional Analysis of Turnover in the Lower Federal Courts, 1900-1987." Journal of Politics 52 (May 1990): 457-76.

Bermant, Gordon; Schwarzer, William; Sussman, Edward; and Wheeler, Russell. Imposing a Moratorium on the Number of Federal Judges. Washington, D.C.: Federal Judicial Center, 1993.

Chase, Harold; Krislov, Samuel; Boyum, Keith; and Clark, Jerry. Biographical Dictionary of the Federal Judiciary. Detroit: Gale Research Company, 1976.

Eskridge, William N., Jr. "Overriding Supreme Court Statutory Interpretation Decisions." Yale Law Journal 101 (1991): 331-455.

Federal Judicial Center, Administrative Office of the Courts. History of the Authorization of Federal Judgeships Including Procedures and Standards Used in Conducting Judgeships Surveys. Washington, D.C.: Administrative Office of the U.S. Courts, 1991.

Gely, Rafael, and Spiller, Pablo T. "The Political Economy of Supreme Court Con- 
stitutional Decisions: The Case of Roosevelt's Court-Packing Plan." International Review of Law and Economics 12 (1992): 45-67.

Goldman, Sheldon. "Reagan's Judicial Legacy: Completing the Puzzle and Summing Up." Judicature 72 (1989): 318-30.

Greene, William H. Econometric Analysis. New York: McMillan, 1992.

Killian, Johnny H., and Beck, Leland E., eds. The Constitution of the United States: Analysis and Interpretation. Washington D.C.: U.S. Government Printing Office, 1982.

Maddala, G. S. Limited-Dependent and Qualitative Variables in Econometrics. New York: Cambridge University Press, 1983.

Mathy, Pamela. "Experimentation in Federal Appellate Case Management and the Prehearing Conference Program of the United States Court of Appeals for the Seventh Circuit." Chicago-Kent Law Review 61 (1985): 431-82.

McCubbins, Mathew D.; Noll, Roger G.; and Weingast, Barry R. "Politics and the Courts: A Positive Theory of Judicial Doctrine and the Rule of Law." Southern California Law Review 68 (1995): 1631-83.

Morris, Jeffrey B. Federal Justice in the Second Circuit. New York: Second.Circuit Historical Committee, 1987.

Newman, Jon O. "'Restructuring Federal Jurisdiction: Proposals to Preserve the Federal Judicial System." University of Chicago Law Review 56 (1989): 761-77.

Office of the Attorney General. Annual Reports of the Attorney General. Washington, D.C.: U.S. Government Printing Office, 1872-1894.

Posner, Richard A. The Federal Courts: Crisis and Reform. Cambridge Mass.: Harvard University Press, 1985.

Roberts, R. B.; Maddala, G. S.; and Enholm, Gregory. "Determinants of the Requested Rate of Return and the Rate of Return Granted in a Formal Regulatory Process." Bell Journal of Economics 9 (Autumn 1978): 611.

Rowland, C. K., and Todd, Bridget J. "Where You Stand Depends on Who Sits: Platform Promises and Judicial Gatekeeping in the Federal District Courts." Journal of Politics 53 (1991): 175-85.

Smith, Christopher E. Courts, Politics, and the Judicial Process. Chicago: Nelson Hall, 1993.

Snyder, Susan, and Weingast, Barry R. "The American System of Shared Powers: The President, Congress, and the NLRB." Unpublished manuscript. Stanford, Calif.: Stanford University, July 1994.

Spiller, Pablo T., and Spitzer, Matthew. "Judicial Choice of Legal Doctrines." Journal of Law, Economics and Organization 8 (1992): 8-46.

Spriggs, James F., and Wahlbeck, Paul J. "Calling It Quits: Strategic Retirement on the Federal Courts of Appeals, 1983-1991." Political Research Quarterly 48 (1995): 573-97.

Starr, Kenneth. "The Supreme Court and the Federal Judicial System." Case Western Reserve Law Review 42 (1992): 1209-22.

Stigler, George J. "Law or Economics?' Journal of Law and Economics 35 (1992): 455-68.

Surrency, Edwin C. History of the Federal Courts. New York: Oceana Publications, 1987. 
Toma, Eugena F. "Congressional Influence and the Supreme Court: The Budget as a Signaling Device." Journal of Legal Studies 20 (January 1991): 131-46.

Tomasi, Timothy B., and Velona, Jess A. "All the President's Men? A Study of Ronald Reagan's Appointments to the U.S. Court of Appeals." Columbia Law Review 87 (1987): 766-93.

Wenner, Lettie M., and Ostberg, Cynthia. "Restraint in Environmental Cases by Reagan-Bush Judicial Appointments." Judicature 77 (1994): 217.

Zuk, Gary; Gryski, Gerald S.; and Barrow, Deborah J. "Partisan Transformation of the Federal Judiciary." American Politics Quarterly 21 (1993): 439-57. 